\title{
EXPERIMENTAL EVALUATION OF LOCAL ANAESTHETIC SOLUTIONS USING RAT INFRAORBITAL NERVE BLOCK
}

\author{
L. BRIAN READY AND B. RAYMOND FINK
}

\begin{abstract}
The analgesic effectiveness of various local anaesthetic solutions was measured in the distribution of the infraorbital nerve of the rat. Using Sprague-Dawley rats sedated with phenobarbitone $25 \mathrm{mg} / \mathrm{kg}$ intraperitoneally and a simple stereotactic technique, $0.2 \mathrm{ml}$ of solution was deposited at the infraorbital notch. The onset and duration of analgesia were ascertained by timing the unilateral absence of aversive response to pinching the upper lip, tested at intervals of five minutes. The experiments were performed with coded solutions, the entire code being preserved intact until completion of the study. Solutions were tested on sets of eight animals weighing $500-600 \mathrm{~g}$. The average duration (minutes \pm S.D.) of analgesia produced by the respective injectates was as follows:

$\begin{array}{llll}\text { Lidocaine } 0.5 \% & -42 \pm 12 & \text { Procaine 1.5\% } & -46 \pm 13 \\ \text { Lidocaine 1.0\% } & -47 \pm 10 & \text { 2-Chloroprocaine } 1.5 \%-38 \pm 9 \\ \text { Mepivacaine } 0.5 \% & -58 \pm 13 & \text { Bupivacaine 0.5\% } & -100 \pm 40 \\ \text { Mepivacaine 1.0\% } & -78 \pm 23 & \text { Etidocaine } 1.0 \% & -59 \pm 25 \\ \text { Procaine } 0.5 \% & -0 \pm 0 & \text { Tetracaine } 0.2 \% & -0 \pm 0 \\ \text { Procaine } 1.0 \% & -34 \pm 10 & \text { Tetracaine 0.3\% } & -0 \pm 0\end{array}$

Comparison with other animal models used to evaluate conduction block indicates that this technique affords an improved, standardized and reliable experimental guide to the clinical analgesic properties of local anaesthetic agents.
\end{abstract}

AlBÉRT AND Löfström have described the use of ulnar nerve block in human volunteers to evaluate anaesthetic agents. ${ }^{1,2}$ Löfström has subsequently reviewed experience with this technique $;^{3,4}$ but this approach is obviously limited to preparations with which safety and efficacy have been previously determined in animals. Several in vivo methods of evaluating local anaesthetics in animal models have been proposed, but none has gained general acceptance. ${ }^{5}$ The experimental nerve block tests have been restricted to the sciatic nerve block in rats ${ }^{6-10}$ and guinea pigs, ${ }^{11,12}$ but these techniques are not exact enough to serve as a standardized laboratory method. Thus a systematic comparison of various drugs in current clinical use has not been available.

We have used a recently described stereotactic technique for blocking the infraorbital nerve of the rat in vivo ${ }^{13}$ to measure the duration of analgesic block produced by various currently used local anaesthetic solutions. In brief, a molded guide is placed against the animal's hard

L. Brian Ready, M.D., F.R.C.P.(C.), Assistant Professor, and B. Raymond Fink, M.D., Professor, Department of Anesthesiology, University of Washington, Seattle, Washing, 98195. Supported in part by A.R.C. Grant and Astra Pharmaceuticals. Presented at the Second World Congress on Pain, September, 1978, Montreal, Quebec, Canada. palate through which a needle is passed. The length of the needle is $12 \mathrm{~mm}$ and is such that the point just reaches the infraorbital notch, through which the infraorbital nerve emerges from the skull.

\section{METhods}

The infraorbital nerve of the rat is two to three millimetres in diameter and supplies and upper lip and whisker area. The animals used in this study were retired male breeder rats of the SpragueDawley strain weighing 500 to 600 grams. The animals were lightly anaesthetized with intraperitoneal phenobarbitone $25 \mathrm{mg}$ per kilogram. This degree of sedation abolished the righting reflex but did not interfere with the generalized aversive response to pinching the upper lip with artery forceps. $0.2 \mathrm{ml}$ of the test solution was injected unilaterally on the right side. The intact left side served as control for comparing the responses on the two sides.

The solutions studied were coded so that the observer was unaware of their composition. The code was not broken until after completion of the study. All blocks were done and all observations were made by a single investigator.

Only animals in which the aversive response 
was abolished within 60 seconds of the time of injection were included in the study. The animals were tested at five-minute intervals thereafter until the first sign of return of the aversive response on the injected side.

The experiments with an individual solution were repeated until eight animals showed a complete block of the aversive response as defined above, or until eight consecutive failures occurred.

The following solutions were tested: lidocaine 0.5 per cent, lidocaine 1.0 per cent, mepivacaine 0.5 per cent, mepivacaine 1.0 per cent, procaine 0.5 per cent, procaine 1.0 per cent, procaine 1.5 per cent, 2-chloroprocaine 1.5 per cent, bupivacaine 0.5 per cent, etidocaine 1.0 per cent, tetracaine 0.2 per cent, and tetracaine 0.3 per cent. The solvent in all cases contained preservative and enough sodium chloride to make the solution approximately isotonic with plasma.

\section{Results}

The average durations of analgesic block for the twelve solutions investigated are shown in Table I. Complete block was obtained with lidocaine 0.5 per cent, lidocaine 1.0 per cent,
TABLE I

Duration of analgesic Block Following $l$ V Vivo INFRAORBITAL NERVE BLOCK IN THE RAT*

\begin{tabular}{lcc}
\hline Injectate & $\begin{array}{c}\text { Duration } \\
\text { (Min. } \pm \text { S.D.) }\end{array}$ & $\begin{array}{c}\text { Incidence } \\
\text { of Blocks }\end{array}$ \\
\hline Lidocaine 0.5\% & $42 \pm 12$ & $8 / 14$ \\
Lidocaine $1.0 \%$ & $47 \pm 10$ & $8 / 10$ \\
Mepivacaine 0.5\% & $58 \pm 13$ & $8 / 10$ \\
Mepivacaine 1.0\% & $78 \pm 23$ & $8 / 8$ \\
Procaine 0.5\% & $0 \pm 0$ & $0 / 8$ \\
Procaine $1.0 \%$ & $34 \pm 10$ & $8 / 10$ \\
Procaine $1.5 \%$ & $46 \pm 13$ & $8 / 10$ \\
2-Chloroprocaine $1.5 \%$ & $38 \pm 9$ & $8 / 11$ \\
Bupivacaine 0.5\% & $100 \pm 40$ & $8 / 8$ \\
Etidocaine $1.0 \%$ & $59 \pm 25$ & $8 / 10$ \\
Tetracaine $0.2 \%$ & $0 \pm 0$ & $0 / 8$ \\
Tetracaine $0.3 \%$ & $0 \pm 0$ & $0 / 8$ \\
\hline
\end{tabular}

${ }^{*} 0.2$ cc. solution injected; onset of block $z$ one minute.

mepivacaine 0.5 per cent, mepivacaine 1.0 per cent, procaine 1.0 per cent, procaine 1.5 per cent, 2-chloroprocaine 1.5 per cent, bupivacaine 0.5 per cent, and etidocaine 1.0 per cent, which respectively lasted $42 \pm 12,47 \pm 10,58 \pm 13,78 \pm$ $23,34 \pm 10,46 \pm 13,38 \pm 9,100 \pm 40$ and $59 \pm 25$ minutes ( \pm S.D.).

By the criteria for complete block, the

TABLE II

Duration (min) or Local Anaesthetic Blocks From In Vivo Animal Experiments*

\begin{tabular}{|c|c|c|c|c|c|c|c|}
\hline & & $\begin{array}{c}\text { Truant \& } \\
\text { Wiedling } \\
\text { 1959† } \\
\text { Ref. } 7\end{array}$ & $\begin{array}{c}\text { Aström \& } \\
\text { Persson } \\
\text { 1961† } \\
\text { Ref. } 8\end{array}$ & $\begin{array}{l}\text { Aberg } \\
1972 \ddagger \\
\text { Ref. } 9\end{array}$ & $\begin{array}{l}\text { Adams, } \\
\text { et al. } \\
1972 \ddagger \\
\text { Ref. } 10\end{array}$ & $\begin{array}{c}\text { Luduena \& } \\
\text { Hoppe } \\
\text { 1951 } \\
\text { Ref. } 12\end{array}$ & $\begin{array}{c}\text { Ready \& } \\
\text { Fink } \\
1979 \text { (present } \\
\text { study) }\end{array}$ \\
\hline \multirow{4}{*}{ \% Lidocaine } & {$[0.25$} & & & & 100 & & \\
\hline & 0.5 & & 28 & & 120 & & 42 \\
\hline & 1.0 & 69 & 44 & & 140 & & 47 \\
\hline & 2.0 & & 92 & & 160 & & \\
\hline \multirow[t]{2}{*}{$\%$ Mepivacaine } & {$[0.5$} & & & 55 & & & 58 \\
\hline & {$[0.125$} & & & & 125 & & \\
\hline \multirow{3}{*}{ \%Bupivacaine } & 0.25 & & & 55 & 175 & & \\
\hline & 0.5 & & & 85 & 215 & & 100 \\
\hline & {$[0.5$} & & 0 & & & 15 & \\
\hline \multirow[t]{3}{*}{$\%$ Procaine } & 1.0 & & 6 & & & 23 & 34 \\
\hline & 2.0 & & 68 & & & 32 & \\
\hline & {$[0.125$} & & & & 160 & & \\
\hline \multirow[t]{3}{*}{$\%$ Tetracaine } & 0.25 & & & & 190 & & \\
\hline & L0.5 & & & & 230 & & \\
\hline & & \multicolumn{3}{|c|}{ Rat sciatic nerve block } & & $\begin{array}{l}\text { Guinea pig } \\
\text { sciatic nerve } \\
\text { block }\end{array}$ & $\begin{array}{l}\text { Rat infra- } \\
\text { orbital nerve }\end{array}$ \\
\hline
\end{tabular}

*Only studies done using peripheral nerve block methods with agents free of epinephrine are listed. † Motor paralysis used as criterion for block.

$\ddagger$ Data estimated from graphs. 
analgesia produced with procaine 0.5 per cent; tetracaine 0.2 per cent; and tetracaine 0.3 per cent was incomplete.

\section{Discussion}

In 1957, Bonica reviewed guidelines for the clinical investigation of local anaesthetics. ${ }^{14} \mathrm{He}$ noted "a conspicuous lack of standardization of models used to study local anaesthetic drugs in the laboratory." He further noted the differences in response of different species of animals to the action of local anaesthetics. Such differences may explain the failure of procaine 0.5 per cent, tetracaine 0.2 per cent and tetracaine 0.3 per cent to produce complete block in this study as defined by our criteria.

Camougis and Takman have surveyed in vivo methods of evaluating local anaesthetics in animal models. ${ }^{5}$ It appears that peripheral nerve blockade has been used only with either the rat or the guinea pig sciatic nerve. The data obtained with these two models are summarized in Table II. The wide variations in the data are probably explicable by differences in technique, preparation, criteria for block duration and conditions of observation where precautions to exclude observer bias were not taken. The fully standardized technique employed in the present study is simple and economical and produces reasonably sharply defined onset and end points. The clinically effective concentrations of local anaesthetics consistently produced an 80 per cent success rate in the model, with the exception of tetracaine. We feel that, to facilitate standardization in an animal model, it is justified to define a successful block in terms of its speed of onset. We noted than when blocks did not occur within 60 seconds, they tended not to occur at all. Possibly on such occasions the small volume of block solution used was not deposited in the immediate vicinity of the infraorbital nerve. Variations in rat size may have been a contributing factor.

In the case of solutions which produced no block (procaine 0.5 per cent and tetracaine 0.2 per cent and 0.3 per cent), observations were continued at five-minute intervals for one hour. Although the aversive response was occasionally diminished, it was not abolished in any animal by these solutions.

\section{SUMMARY}

The analgesic effectiveness of various local anaesthetic solutions was measured in the dis- tribution of the infraorbital nerve of the rat utilizing a simple stereotactic in viro injection technique. A comparison with other methods of evaluating conduction block, both animal and human, suggests that this technique affords an improved, standardized and reasonably reliable experimental guide to the clinical analgesic properties of local anaesthetics.

\section{REFERENCES}

I. AlbíRT, J. \& LöfströM, B. Bilateral ulnar nerve blocks for the evaluation of local anesthetic agents. Acta Anesthesiol. Scand. 5: 99 (1961)

2. ALBÉRT, J. \& LöFSTRÖM, B. Bilateral nerve blocks for the evaluation of local anesthetic agents. Acta Anesthesiol. Scand. 9: 1 (1965).

3. Löfström. B. The blacking effects of some local anesthetics commonly used in clinical practice. International Encyclopedia of Pharmacology and Therapeutics, sect. 8, 1: 167 (1971).

4. Löfström, B. Ulnar nerve blockade for the evaluation of local anesthetic agents. Br. J. Anaesth. 47: 297 (1975).

5. Camougis, G. \& Takman, B. Nerve and nervemuscle preparations (as applied to local anesthetics). Methods Pharmacol. l: 1 (1971).

6. Truant, A. Studies on the pharmacology of meprylcaine (oracaine), a local anesthetic. Arch. Int. Pharmacodyn. Ther. //5: 483 (1958)

7. Truant. A.\& Wiedling. $S$. A contribution to the pharmacological and toxicological evaluation of a new local anesthetic di-N-methyl-pipecolyl-2, 6xylidide. Acta Chir. Scand. / 65: 351 (1958-59).

8. Aström. A. \& PERsSON, N. Some pharmacological properties of 0 -methyl-d-propyl-amino propionanilide, a new local anesthetic. $\mathrm{Br}$. J. Pharmacol. 16: 32 (1961).

9. AlberG. G. Toxicologic and local anesthetic effects of optically active isomers of two local anesthetic compounds. Acta Pharmacol. Toxicol. 3I: 273 (1972).

10. ADAMS, H. et al. Local anesthetic activity and acute toxicity of (土)-2-(N-ethyl-propylamin)-2',6'butyroxylidide, a new long-acting agent. J. Pharm. Sci. 61: 1829 (1972)

11. SChackell. L. Tests of local anestheties by sciatic nerve block in the intact guinea pig. Anesth. Analg. 14: $20(1935)$

12. Luduena, F. \& Hoppe, J. 2-phenyl-4-thiazolidone derivatives as local anesthetics. J. Am. Pharm. Assoc. 40: 132 (195l).

13. FINK, B. Neurokinetics of lidocaine in the infraorbital nerve of the rat in vivo. Anesthesiology $42: 731$ (1975).

14. BoniCA. J. Clinical investigation of local anesthetics. Anesthesiology 18: 110 (1957). 


\section{RÉsumé}

L'efficacité analgésique de quelques solutions et concentrations d'anesthésiques locaux a été évaluée dans le territoire de distribution du nerf infraorbital. Chez des rats de race SpragueDawley suus sédation au phénobarbitone à la dose de $25 \mathrm{mg} \cdot \mathrm{kg}^{-1}$ administrée par voie intrapéritonéale et sous contrôle stéréotaxique simple, on a injecté une solution de $0.2 \mathrm{ml}$ au niveau de l'échancrure infraorbitale. Le début et la durée de l'analgésie ont été mesurés en chronométrant la disparition unilatérale de la réaction d'aversion provoquée par le pincement de la lèvre inférieure recherchée aux cinq minutes. On a utilisé des solutions codées dont le secret a été gardé jusqu'à la fin de l'étude. Les tests ont été effectués sur des séries de huit animaux pesant de 500 à $600 \mathrm{~g}$. La durée moyenne (en minutes $\pm \mathrm{E}$.T.) d'analgésie produite par les injections ont été comme suit:

$\begin{array}{llll}\text { Lidocaine } 0.5 \% & -42 \pm 12 & \text { Procaine } 1.5 \% & -46 \pm 13 \\ \text { Lidocaine 1.0\% } & -47 \pm 10 & \text { Chloroprocaine 1.5\% } & -38 \pm 9 \\ \text { Mépivacaine } 0.5 \% & -58 \pm 13 & \text { Bupivacaine 0.5\% } & -100 \pm 40 \\ \text { Mépivacaine } 1.0 \% & -78 \pm 23 & \text { Etidocaine 1.0\% } & -59 \pm 25 \\ \text { Procaine } 0.5 \% & -0 \pm 0 & \text { Tétracaine } 0.2 \% & -0 \pm 0 \\ \text { Procainc 1.0\% } & -34 \pm 10 & \text { Tétracaine } 0.3 \% & -0 \pm 0\end{array}$

Si on compare cette technique avec les autres utilisées pour l'évaluation d'un blocage, on constate qu'elle nous permet une évaluation améliorée, standardisée et fiable des propriétés analgésiques des agents anesthésiques locaux. 